\title{
Model of Optimal Forest Management Unit Area for a
}

\section{Sustainable Forest Resource Administration}

\author{
Wahyu Andayani \\ Department of Forest Management, Faculty of Forestry, Gadjah Mada University, Yogyakarta 55281, Indonesia
}

\begin{abstract}
Deforestation is one of the most crucial problems in Indonesia. It creates a number of environmental problems, e.g., landslides, loss of biological diversity, and decrease of carbon sequestration which are impacting human lives. There are a number of underlying causes, often stemmed from the emphasis on a particular forest management objective. Despite numerous forest policies and regulations established by the government, deforestation continues to happen. Quite often, the policies and regulations remain "paper tiger", which means ineffectual on the ground. One of the contributing factors to deforestation is the lack of custodian for the management of the forests. The regulation, such as law No. 41/1999, stipulates that all state forests must be managed under a FMU (forest management unit) as the custodians. The objective of this research is to develop an optimal model for FMU. Using the LGP (linear goal programming), this research attempts to develop an optimum model for conservation areas. It assumes that the existing zoning approach implemented by the government in conservation areas is inappropriate. The optimum zoning model is expected to improve forest management and restore the forest function as a life supporting system and biological diversity conservation.
\end{abstract}

Key words: FMU, LGP, optimum zoning.

\section{Nomenclature}

$\begin{array}{ll}Z & \text { The objective function } \\ X_{i j}, d_{i}^{-}, & \text {Non-negative constraint } \\ d_{i}^{+} \geq 0 & \begin{array}{l}\text { The preemptive priority }\left(P_{k}>P_{k+1}\right) \text { assigned to } \\ \text { goal } k\end{array} \\ P_{k} & \begin{array}{l}\text { The cardinal weights assigned to the deviational } \\ \text { variables of goal } i \text { at priority level } k\end{array} \\ W_{i k}^{+}, W_{i k} & \text { The negative and positive deviations associated } \\ d_{\mathrm{i}}^{-}, d_{i}^{+} & \begin{array}{l}\text { with goal } i \\ a_{i j}\end{array} \\ b_{i} & \begin{array}{l}\text { The technological coefficient associated with } X, \\ \text { in goal } i\end{array} \\ X_{j} & \begin{array}{l}\text { The } i \text { th goal level } \\ \text { Decision variable on activities as a sub }\end{array} \\ g_{k j} & \begin{array}{l}\text { The technological coefficient of general } \\ \text { constraint }\end{array} \\ C_{k} & \text { The amount of resources } k \text { th }\end{array}$

\section{Introduction}

Indonesia's forest area spans about 130 million ha, and it is designed into different types/categories according to the biophysical characteristics and the usages. More than 46\% (approximately 56 million ha)

Corresponding author: Wahyu Andayani, doctor, professor, research field: forest resource economics. E-mail: wandayani@ugm.ac.id; andayani_wahyu@yahoo.com. of the forests is not intensively managed, a large fraction of which is allocated for non-production forests, i.e., protection forests and conservation forests. Meanwhile, intensive management through forest concessionaires (known as "bussines permits for timber forest product utilization") is practiced in production forests, which account for $36 \%$ of the country's forestland. However, conflicts between the forest managers and local communities occur in both types of forests, stemmed from: land encroachment, illegal cutting, non-forest uses, and unclear delineation between state forests, customary forest and village forests.

The conflicts to some extent result in the increase of the degraded forest resources that eventually reduce the forest function as life supporting system. The establishment of FMUs (forest management units) is viewed as an enabling condition for improved forest practices. Therefore, the implementation should be accelerated. This is laid and mandated in the Indonesian Forest Law UU No. 41/1999 and a number of implementing regulations, including Government 
Regulation No. 3 of 2008 jo. No. 6 of 2007, which stipulates that all state forest lands must be divided into FMUs as the national strategy for forest administration.

This paper aims to design a FMU model that integrates ecological, social and economic aspects of forests. It focuses on designing a model for FMU conservation, principally in national parks. Governmental Regulation Decree No. 44/2004 on Forest Planning also mandates the establishment of FMUs in national parks as a strategy of efficient management and forest sustainability. Currently, 30 FMUs have been established, and another 20 are expected to be created. In line with the theme of the seminar "Forest and Biodiversity", the management model of ecosystem-based conservation areas is part of biodiversity programs, and aims to provide necessary information and technology to support sustainable management and uses of conservation areas.

The focus on national parks for the FMU model is particularly directed by the fact that they possess genuine ecosystems, are managed accordingly to zoning systems, and are utilized for various purposes such as research, education, socio-cultural purposes, recreation and tourisms (Article 1 (14) UU No. 5/1990 on Conservation of Life Natural Resource and Its Ecosystem). For developing the appropriate model for national park zoning, this paper employs LGP (linear goal programming). This paper assumes that the current area zoning can be improved [1].

\section{Literature Review}

\subsection{Economic Functions of National Park Ecosystem}

Studies on the total economic value of national parks are still limited. Most of the existing studies are partial, focusing only for instance on: the economic values of water using productivity and expenditure, the protection values of forests using CVM (contingent valuation method), economic values of forest carbon (sequestration) using market valuation method, economic values of forest tours using travelling cost method, and other studies on natural parks' assets, both tangible and intangible [2]. Despite the fact that national parks play an important role as life supporting system, it is rather difficult to explain to the public about their economic functions. This is because national parks contain numerous products with high intangible values. Therefore, it is important to educate the economic values of national parks to transformative strategies. Transformation here is meant as a policy or regulation that enables the (economic) values fully understood by the whole society.

Conservation areas, including national parks, are public goods; rarely the areas are free of social problems such as encroachments and differing perception on the tenurial status between the state and local communities. In addition, national parks are often inhabited by local people, who depend on the resources for their livelihood [3].

From the perspective of economic theory, national parks produce outputs that do not have market prices. The products are intangible and cannot be valued as the tangible products such as timber [4]. With such a characteristic, the market prices of intangible products can be proximated through willingness to pay and willingness to sell $[5,6]$. The characteristics of the economic values of national parks should be well understood for the improved planning processes.

\subsection{Linear Goal Programming and Its Implementation on Forest Zoning}

As been said in the introduction, this paper attempts to design a model for optimum management of national parks. The considerations include: (1) national parks are a conservation pillar functioning protection, preservation and utilization; (2) the biodiversity aspects (key features) of national parks should be well preserved for the optimal uses. Such characteristics later constrain the objectives of management strategies of national parks. Multiple objectives are therefore made for national park 
management, instead of single objective [6-8].

The challenge is the potentially conflicting objectives. The management strategies must simultaneously elaborate ecosystem, social and economic aspects. LGP is widely used for solving the conflicting objectives. It is often used in: (1) production planning; (2) watershed spatial planning; and (3) area zoning of conservation, production, protection and buffer areas.

Optimum model of FMU conservation, which promotes sustainable management of national parks, must provide solutions for zoning, according to the functions, and considering the following principles: (1) protecting and preserving the ecosystem as life support system; (2) fostering the sustainability of the biological diversity; (3) improving the roles of national parks for the environment and local communities; (4) preventing/minimizing disruption or disturbances; (5) enhancing regional development; and (6) creating jobs/employment [9, 10]. The core/essence of linear goal programming is minimizing the conflicts of interests of different stakeholders on the benefits from the national parks. Therefore, the managers must carefully and wisely arrange the zoning of the national parks, in the mathematical terms, minimizing the deviation of each is used by considering constraints and priorities that have been drawn up.

Generally, steps taken in the analysis using LGP include: (1) determining the objectives for decision making (decision variables); (2) indentifying the constraints; (3) setting the priorities according to the characteristics of the area that has specific key biodiversity features; and (4) weighting according to the rational and general criteria. In resort-based management of national parks, determining the model of LGP is best with priorities and weighting, with the following variables for considerations: (1) resort area for zoning determination; (2) accessibility of the area; (3) scale of forest area can be managed according to the determined functions; (4) availability of human resources and personnel; (5) objectives of management priorities; (6) activities of local communities in the national parks according to time dimensions; (7) socio-economic conditions of local communities; (8) the level of dependency of local communities on the resources; and (9) the economic resilience-measured by the economic contribution of the area to the total income within a certain period. The variables are then constructed in the model of linear goal programming.

\section{Model Development}

\subsection{General Model of $L G P$}

\subsubsection{LGP Model (without Priorities)}

$$
\begin{aligned}
\operatorname{Minimum} Z & =\sum_{i=1}^{m} W_{i}\left(d_{i}^{+}+d_{i}^{-}\right) \\
& =\sum_{i=1}^{m} W_{i}^{+} d_{i}^{+}+W_{i}^{-} d_{i}^{-}
\end{aligned}
$$

Subject to constraint

$$
\begin{gathered}
\sum_{j=1}^{n} a_{i j} X_{j}+d_{i}^{-}-d_{i}^{+}=b_{i} \\
i=1,2 \ldots(m) \text { (objective) } \\
\sum_{j=1}^{n} g_{k j} X_{j} \leq \text { or } \geq C_{k} \\
k=1,2 \ldots(p)(\text { functional constraint) } \\
\text { and } \mathrm{j}=1,2 \ldots . .(n) \\
X_{j}, d_{i}^{-}, \text {and } d_{i}^{+} \geq 0 \\
d_{i}^{-} \text {and } d_{i}^{+}=0
\end{gathered}
$$

which are the source from Refs. [6, 7, 11].

3.1.2 LGP Model (Pre-emptive Weights, Ordinal Ranking)

$$
\text { Minimum } Z=\sum_{i=1}^{m}\left(P_{y} W_{i, y}{ }^{+} d_{i}^{+}+P_{s} W_{i, s}{ }^{-} d_{i}^{-}\right)
$$

which are the source from Refs. $[6,7,11]$.

\subsection{Description of Variables Used in LGP for National Park Case Study}

The overall objective of national park management is to discover a strategy to manage the area which 
could preserve biodiversity, accommodate social interest and economy, generate efficient and effective economic benefit and provide synergy to national and international policies and regulations.

In summary, the model formulated in Section 3.1.1 and Section 3.1.2 should be able to address these points below:

(1) the objective to minimize deviation and the implementation to minimize conflict of interest among several sectors participating in managing the forest area functions as national park in relation to zoning, management goal and essential key features which represent the characteristics s of a national park;

(2) the determination of management priorities to properly distribute zone allocation and to match with each zone characteristic without ignoring the aspects of ecosystem, social and economic simultaneously.

All the variables are formulated into mathematical model mentioned in Section 3.1.1 and Section 3.1.2 to determine the zone allocation which is matched with the real challenges in the area.

\section{Results and Discussion}

\subsection{Implementation of Conservation Area Zoning}

Before further explaining studies on optimum zoning model in national parks - the case of Berbak
National Park [12], Gede Pangrango National Park [13], and Alas Purwo National Park [3] — this paper briefly describes the profiles of national parks in Java, both non-FMU conservation and FMU conservation as shown in Table 1.

In Java, there are 12 national parks, eight of which have been established as FMU conservation. As a FMU conservation, the national parks must create/establish/ensure: management goals/objectives (ecosystem-based, short-, medium-, long-term goals), institutional frameworks (vertical and horizontal), funding mechanisms, organizational structures, management strategies (based on resorts/regions, biodiversity characteristics), business plan, tenurial security, analysis of managed products and services, and adequate facilities. From scant observations, despite being definitively established as FMU conservation, the national parks are yet to be optimally managed. Support of guidelines from the government are still needed at the initial phases so that the national parks can autonomously function as an ecosystem-minded business unit.

\subsection{Optimal Zoning Model for National Parks}

Studies on optimal zoning model for several national parks outlined in Tables 2-4 are shown as follows.

Table 1 National parks in Java Island.

\begin{tabular}{llcl}
\hline No. & National parks (TN (Taman national)) & Province & Area (ha) \\
\hline 1 & & TN Ujung Kulon & $122,956.00$ \\
2 & TN Gunung Halimun & West Java & $113,357.00$ \\
3 & TN Karimunjawa & West Java & $111,625.00$ \\
4 & TN Gunung Merbabu & Central Java & $5,725.00$ \\
5 & TN Gunung Merapi & Central Java & $6,410.00$ \\
6 & TN Alas Purwo & Jogyakarta & $43,420.00$ \\
7 & TN Meru Betiri & East Java & $58,000.00$ \\
8 & TN Baluran & East Java & $25,000.00$ \\
\hline & & East Java & \\
\hline 9 & TN Gunung Gede Pangrango & Non-FMU conservation & $22,851.00$ \\
10 & TN Gunung Cereme & West Java & $15,859.00$ \\
11 & TN Kepulauan Seribu & West Java & $107,489.00$ \\
12 & TN Bromo Tengger Semeru & West Java & $50,276.00$ \\
\hline
\end{tabular}

Source: the Republic of Indonesia Department of Forestry Document, 2011. 
Table 2 Optimum distribution of zones of Gede Pangrango Mount National Park.

\begin{tabular}{|c|c|c|c|c|c|c|c|}
\hline \multirow[b]{2}{*}{ No. } & \multirow[b]{2}{*}{ Zone classification } & \multicolumn{2}{|c|}{ Existing condition } & \multicolumn{2}{|c|}{ Optimum condition } & \multicolumn{2}{|c|}{ Changes } \\
\hline & & $\begin{array}{l}\begin{array}{l}\text { Area } \\
\text { (ha) }\end{array} \\
\end{array}$ & $\begin{array}{l}\text { Percentage } \\
(\%)\end{array}$ & $\begin{array}{l}\text { Area } \\
\text { (ha) }\end{array}$ & $\begin{array}{l}\text { Percentage } \\
(\%)\end{array}$ & $\begin{array}{l}\text { Area } \\
\text { (ha) }\end{array}$ & $\begin{array}{l}\text { Percentage } \\
(\%)\end{array}$ \\
\hline 1 & Sanctuary & $9,612.60$ & 42.07 & $9,567.10$ & 41.86 & $(45.44)$ & $(0.21)$ \\
\hline 2 & Wilderness & $7,175.40$ & 31.40 & $7,428.20$ & 32.50 & 252.84 & 1.10 \\
\hline 3 & Utilization & $1,330.40$ & 5.82 & $1,305.30$ & 5.70 & $(25.10)$ & $(0.12)$ \\
\hline 4 & Rehabilitation & $4,367.20$ & 19.11 & $3,800.60$ & 16.60 & $(566.60)$ & $(2.51)$ \\
\hline 5 & Traditional & 312.10 & 1.37 & 749.80 & 3.34 & 437.70 & 1.97 \\
\hline 6 & Conservation of Owa Jawa & 50.10 & 0.22 & 0 & 0 & $(50.10)$ & $(0.22)$ \\
\hline \multirow[t]{2}{*}{7} & Special zone & 3.20 & 0.01 & 0 & 0 & 3.20 & 0.01 \\
\hline & Total & $22,851.00$ & 100.00 & $22,851.00$ & 100.00 & & \\
\hline
\end{tabular}

Source: Ref. [13].

Percentage of change $=$ percentage of existing condition - percentage of optimum condition.

Table 3 Optimum distribution of zones of Berbak National Park.

\begin{tabular}{|c|c|c|c|c|c|c|c|}
\hline \multirow[b]{2}{*}{ No. } & \multirow[b]{2}{*}{ Zone classification } & \multicolumn{2}{|c|}{ Existing condition } & \multicolumn{2}{|c|}{ Optimum condition } & \multicolumn{2}{|c|}{ Changes } \\
\hline & & $\begin{array}{l}\text { Area } \\
\text { (ha) }\end{array}$ & $\begin{array}{l}\text { Percentage } \\
(\%)\end{array}$ & $\begin{array}{l}\text { Area } \\
\text { (ha) }\end{array}$ & $\begin{array}{l}\text { Percentage } \\
(\%)\end{array}$ & $\begin{array}{l}\text { Area } \\
\text { (ha) }\end{array}$ & $\begin{array}{l}\text { Percentage } \\
(\%)\end{array}$ \\
\hline 1 & Sanctuary zones & $71,445.60$ & 43.90 & $133,002.40$ & 81.74 & $61,556.80$ & 37.84 \\
\hline 2 & Wilderness zones & $61,758.30$ & 37.96 & $15,755.20$ & 9.70 & $(46,003.10)$ & $(28.26)$ \\
\hline 3 & Utilization & $6,882.70$ & 4.24 & $7,100.20$ & 4.40 & 217.50 & 0.16 \\
\hline 4 & Special (to be defined) & $22,613.40$ & 13.90 & 0 & 0 & 0 & - \\
\hline \multirow[t]{2}{*}{5} & Rehabilitation & 0 & 0 & $6,842.20$ & 4.16 & $6,842.20$ & 4.16 \\
\hline & Total & $162,700.00$ & 100.00 & $162,700.00$ & 100.00 & & \\
\hline
\end{tabular}

Source: Ref. [12].

Percentage of change $=$ percentage of existing condition - percentage of optimum condition.

Table 4 Optimum distribution of zones Alas Purwo National Park.

\begin{tabular}{|c|c|c|c|c|c|c|c|}
\hline \multirow[b]{2}{*}{ No. } & \multirow[b]{2}{*}{ Zone classification } & \multicolumn{2}{|c|}{ Existing condition } & \multicolumn{2}{|c|}{ Optimum condition } & \multicolumn{2}{|c|}{ Changes } \\
\hline & & $\begin{array}{l}\begin{array}{l}\text { Area } \\
\text { (ha) }\end{array} \\
\end{array}$ & $\begin{array}{l}\text { Percentage } \\
(\%)\end{array}$ & $\begin{array}{l}\begin{array}{l}\text { Area } \\
\text { (ha) }\end{array} \\
\end{array}$ & $\begin{array}{l}\text { Percentage } \\
(\%)\end{array}$ & $\begin{array}{l}\begin{array}{l}\text { Area } \\
\text { (ha) }\end{array} \\
\end{array}$ & $\begin{array}{l}\text { Percentage } \\
(\%)\end{array}$ \\
\hline 1 & Sanctuary & $17,200.00$ & 39.60 & $16,600.00$ & 38.20 & $(600.00)$ & $(1.40)$ \\
\hline 2 & Wilderness & $24,767.00$ & 57.00 & $21,986.00$ & 50.60 & $(2,781.00)$ & $(6.40)$ \\
\hline 3 & Utilization & 250.00 & 0.70 & 648.00 & 1.70 & 398.00 & 1.00 \\
\hline 4 & Buffer zone & $1,203.00$ & 2.70 & $2,284.00$ & 5.20 & $1,081.00$ & 2.50 \\
\hline 5 & $\begin{array}{l}\text { Special } \\
\text { (rehabilitation, conservation, } \\
\text { religious purposes) }\end{array}$ & & & $1,902.00$ & 4.30 & $1,902.00$ & 4.30 \\
\hline & Total & $43,420.00$ & 100.00 & $43,420.00$ & 100.00 & & \\
\hline
\end{tabular}

Source: Ref. [3].

Percentage of change $=$ percentage of existing condition - percentage of optimum condition .

Analysis on the optimal zones in the research location (Tables 2-4) reveals information on the changes in the area of each zone from the existing conditions to the optimal conditions. The changes can be either increase or decrease, resulted from:
(1) complete definitive on the field not yet done;

(2) different priorities of each national parks, while elaborating the dependency of local communities on the parks;

(3) provisions made by Ministerial Decree No. P. 
56/Menhut-II/2006 for elaborating additional aspects in other areas/zones (except sanctuary zone, wilderness zone and utilization zone which are strictly regulated by the government).

Thus, the optimum zoning model for FMU conservation covers not only the changes in the existing zones, but also the definitive zoning reconstruction, which means that the managers must be responsively and sensitively aware that the national parks are natural assets containing numerous products and services that must be carefully managed for sustainability $[10,14]$.

The result of the study on organizing optimum zoning in three national parks namely: (1) Gunung Gede Pangrango National Park, (2) Berbak National Park, and (3) Alas Purwo National Park provides us the information regarding the change in the established areas which are core zone, forest zone, utilization zone and rehabilitation zone. That has shown us that the challenges faced by national parks studied are similar which include technical aspect and social economic of the community surrounding the national parks whose lives highly depend on the existence of forest resources in this case is the national park [16, 17]. Therefore, in accordance with the objective of management which is to preserve natural resources and also to address the interest of the community to maintain their economy, national park managers should accommodate all of those conditions. The strategy implemented by national parks managers to meet the objectives stated above is to provide special zone to meet the subsistent needs of the community beside the utilization zone which has the function of meeting economic goal [18-20]. This study considered several critical factors affecting technical aspects and social economy of the community which functioned as challenges in formulating the LGP. On the other side, national parks as conservation areas have multi functions namely protection function as life support, preservation of biodiversity and ecosystem, and utilization function of natural resources based on the principle of sustainability $[15,17]$. Hence, this multi-objectives optimization program is appropriate to determine the strategy to organize the zoning of forest areas which have multi functionalities not only for national parks as conservation areas but also for other forest areas functioning as productive areas.

\section{Conclusions}

Deforestation and forest degradation occurs not only in production forests, but also in other forest types including conservation and protection forests. Swift responses and anticipation are needed to foster the sustainability of the natural resources. With regard to FMU conservation-principally national parks, a number of aspects can be taken into consideration in their management and the policy making. This includes the ecosystem itself and the socio-economic conditions of local communities. The elaboration of multiple aspects in policy making and management of national parks may minimize the potential threats to the resources. A new forest policy development occurred on May 16, 2013; the Highest Court (Mahkamah Konstitusi) ruled customary forests out state forest zones, and handed the areas to the customary communities. This paper expects that this decision can be well-elaborated in the management of the resources and therefore serves as enabling conditions for sustainable management.

\section{Acknowledgments}

In this opportunity, the author would like to thank Ir. Hartono, M.Sc., who has given plenty information, data and inputs based on his experience in managing Alas Purwo National Park. The author also would like to express the same gratitude to Ida Rohaida and Nufit Hari Rachmat for the cooperation especially for sharing their experiences in managing Gunung Gede Pangrango National Park and Berbak National Park.

\section{References}

[1] Saaty, T. 1994. Fundamentals of Decision Making and 
Priority Theory with the Analysis Hierarchy Process. Pittsburgh: RWS Publications.

[2] Bishop, J. T. 1999. Valuing Forests: A Review of Methods and Applications in Developing Countries. London: International Institute for Environment and Development.

[3] Andayani, W. 2012. "Economic Profile of National Park Management through Zoning Optimization Strategy Ecosystem Based." Presented at National Seminar of Re-arranging the Direction of Biodiversity and Ecosistem Conservation for Community Benefit, Yogyakarta.

[4] Sumitro, A. 2005. Forest Resource Economy: An analysis of Forest Revitalization in Indonesia. Yogyakarta: Debut Press.

[5] Hufschmidt, M. M., James, D. E., Meister, A. D., Bower, B. T., and Dixon, J. A. 1987. Edisi Indonesia: Lingkungan Sistem Alami dan Pembangunan, Petunjuk Penilaian Ekonomi (Environmental Natural System and Development, an Economic Valuation Guide). Yogyakarta: Gadjah Mada University Press.

[6] Nasendi, B. D., and Affendi, A. 1985. Linear Programming and Its Variations. Jakarta: Gramedia Press.

[7] Dykstra, D. P. 1984. Mathematical Programming for Natural Resource Management. New York: McGraw-Hill.

[8] Ignizio, J. P. 1976. Goal Programming and Extensions. Lexington, Massachusetts: Health, Lexington Books.

[9] Heinen, J. T., and Mehta, J. N. 2000. "Emerging Issues in Legal and Procedural Aspect of Buffer Zone Management with Case Studies from Nepal." Journal of Environment and Development 9: 45-67.

[10] Steffen, S., and Thorsten, T. 2006. "Beyond Buffer Zone Protection: A Comparative Study of Park and Buffer Zone Products Importance to Villagers Living in Side
Royal Chitwan National Park and to Villagers Living in Its Buffer Zone." Journal of Environment Management 78 (3): 251-67.

[11] Winston, W. L. 1994. Operations Research Applications and Algorithms. Belmont: Dux Bury Press.

[12] Rachmat, N. H. 2011. "Optimization of Zone Designation at Berbak National Park, Jambi Regency." Thesis, Faculty of Forestry, Gadjah Mada University, Yogyakarta.

[13] Rohaida, I. 2011. "The Optimization of Zoning at the Area of Gunung Gede Pangrango National Park, West Java Regency." Thesis, Faculty of Forestry, Gadjah Mada University, Yogyakarta.

[14] Gomes, T., Hernandez, M., Leon, M. A., and Caballero, R. 2006. "A Forest Planning Problem Solved via a Linear Fractional Goal Programming Model.” Forest Ecology and Management 227: 79-88.

[15] Ignizio, J. 1982. Linear Programming in Single and Multiple Objective System. Englewood Cliffs, NJ: Prentice-Hall.

[16] Dixon, J. A., and Sherman, P. B. 1990. Economics of Protected Areas: A New Look at Benefits and Costs. Washington DC: East-West Center, Island Press.

[17] Keeney, R., and Raiffa, H. 1976. Decision with Multiple Objectives: Preferences and Value Tradeoffs. New York: John Wiley.

[18] Boyland, M., Nelson, J., and Bunnell, F. L. 2004. "Creating Land Allocation Zones for Forest Management: A Simulated Annealing Approach." Canadian Journal of Forest Research 34: 1669-82.

[19] Saaty, T. 1980. The Analytic Hierarchy Process. New York: McGraw-Hill.

[20] Pearce, D., and Turner, R. K. 1990. Economics of Natural Resources and the Environment. Hemel Hempstead: Harvester Wheatsheaf. 